\title{
Undervisning i relation till omsorg och lärande i förskola: Flerstämmig undervisning och didaktisk (o)takt?
}

\author{
Ann-Christine Vallberg Roth \\ Malmö universitet \\ Ylva Holmberg \\ Malmö universitet
}

\begin{abstract}
Identifierat problem är inriktat på undervisning i relation till omsorg och lärande, eller med andra ord vad den så kallade "helheten" i policydokument kan innebära och hur den kan framträda i förskolans undervisning. Det finns ett underskott av forskning som belyser området utifrån mer omfattande empiriska studier i samverkansprojekt. Syftet är att, med koppling till ett samverkansprojekt, utveckla kunskap om vad som kan känneteckna undervisning i relation till omsorg och lärande i förskollärares texter och dokumenterade samhandlingar i förskola som skolform i Sverige. Metodologiskt refererar analysen till abduktiv analys i didaktiskt perspektiv. Materialet inkluderar totalt 349 skriftliga dokument och 63 filmtimmar från 121 förskolor/avdelningar i tio kommuner. Källdata utgörs av ord-data och audiovisuella data. Resultatet visar att begreppen undervisning, omsorg och lärande kan framträda som både åtskilda och sammanflätade på olika sätt. Sammantaget fogas analysen samman och prövas genom det övergripande begreppet "flerstämmig undervisning" som kan inrymma "didaktisk (o)takt".
\end{abstract}

\section{INTRODUKTION}

Det föreligger stora behov av att klargöra hur undervisning kan bedrivas i svensk förskola (Skolinspektionen, 2018). Tidigare forskning har varit mer inriktad mot lärande än undervisning i förskola (Vallberg Roth, 2018), även om det också finns studier som varit inriktade på undervisning (se t.ex. Sheridan \& Williams, 2018). I förskola gäller en vid definition av undervisning 
(Proposition 2009/10:165) och artikeln belyser vad som kan känneteckna undervisning i relation till lärande och omsorg i skolformen förskola. Föreliggande studie utgör en del av ett samverkansprojekt ${ }^{1}$ om undervisning i förskola utifrån ett didaktiskt perspektiv (Vallberg Roth, 2017).

\section{Identifierat forskningsproblem - "helhet" $\mathrm{i}$ undervisningen}

Identifierat forskningsproblem $i$ artikeln rör sig om vad som kan menas med "helhet" i anslutning till undervisning i förskola. Helhet kan avse något som betraktas i hela sin omfattning, något som är helt och inte delat, något som är odelbart. Vidare kan helhet avse mer än summan av alla de delar som ingår, den kan även inkludera relationer mellan delarna (jfr Josefsson, 2018; Thelin, 2013). Således kan begreppet helhet referera till "en strävan att söka förstå och närma sig en företeelse i hela sin komplexitet" (Thelin, 2013, s. 33). Frågan är vad som kan avses med helhet $\mathrm{i}$ relation till undervisning $\mathrm{i}$ skolformen förskola.

I skollagen (SFS 2010: 800) är helhet av omsorg, utveckling och lärande något som uttrycks i förhållande till verksamheten i förskolan. Ordet helhet ingår inte $\mathrm{i}$ skollagens formuleringar $\mathrm{i}$ anslutning till grundskola och gymnasieskola, utan enbart i formuleringar om skolformerna förskola, förskoleklass och fritidshem. Den något mer specificerade helheten, med komponenterna omsorg, utveckling och lärande, är uteslutande kopplad till verksamheten i skolformen förskola i skollagen. I förslag till reviderad läroplan har omsorg införts i olika avsnitt och rubriker för att "tydliggöra att omsorg, utveckling och lärande utgör en helhet" i undervisningen (Skolverket, 2018, s. 7). Skrivningarna framhäver också att förskolläraren ska ansvara för helheten. Under målområdet 2.7 är helheten kopplad till undervisning:

Förskolläraren ska i undervisningen ansvara för att omsorg, utveckling och lärande bildar en helhet. (SKOLFS 2018:50, s. 14)

Professionella i Sveriges förskolor tycks kämpa med begreppet "undervisning" i deras dagliga praktiker (Skolinspektionen, 2018). Detta är ett problem som också ligger till grund för ett tre-årigt FoU-program om undervisning i förskola (se not 1), som studien i denna artikel utgör en del av. Det är förskollärare och chefer i projektet som har initierat frågor om undervisning. Och här framträder behov av redskap för undervisning som vilar på vetenskaplig grund och beprövad erfarenhet (RFR, 2012/2013).

\section{Avgränsning}

Det blir omfattande att $\mathrm{i}$ en och samma artikel fokusera begreppen undervisning, omsorg, utveckling och lärande med empiriska exempel. 
Artikeln avgränsas därför till att belysa undervisning i relation till omsorg och lärande med koppling till samverkansprojektet (se not 1).

\section{Syfte och forskningsfrågor}

Syftet är att, utifrån identifierat forskningsproblem med koppling till samverkansprojektet, utveckla kunskap om vad som kan känneteckna undervisning i relation till omsorg och lärande i förskollärares texter och dokumenterade samhandlingar i förskola som skolform i Sverige. Forskningsfrågor som väglett studien är:

- Vad kan känneteckna undervisning i relation till omsorg och lärande i förskollärares texter och dokumenterade samhandlingar i förskola?

- Vilka spår av didaktiska frågor kan uttolkas, i relation till undervisning, omsorg och lärande, i förskollärares texter och dokumenterade samhandlingar i förskola?

Förskollärares texter avser planeringar och uppföljningar av undervisning. Begreppet "samhandling" avser handling mellan minst två aktörer, som exempelvis handling mellan barn-lärare, eller barn-lärare-material. Handling avser något som utförs och innebär aktion - att vara aktiv.

\section{NEDSLAG I TIDIGARE FORSKNING}

Valet av tidigare forskning är kopplat till identifierat forskningsproblem och syfte. Svensk förskola placerar sig i en nordisk tradition med välfärdsstatliga ambitioner som är högt rankade i internationella framställningar (OECD, 2017). Vid en internationell utblick pekar longitudinell forskning på förskollärarens betydelse för verksamhetens kvalitet, och därmed för barns lärande och utveckling (t.ex. Sylva, Melhuish, Sammons, Siraj-Blatchford \& Taggart, 2010). Persson (2015) betonar att "Tidigare forskning har presenterat resultat som pekar på att kvalitet i förskoleverksamheten är en kombination av lyhörd omsorg och hög kvalitet på undervisningen, det senare benämns i den internationella forskningslitteraturen som instructional quality" (s. 123).

I en inventering av förskoleforskning (Tallberg Broman, 2015) visar det sig snarare vara "lärande-sidan" än "undervisnings-sidan" av ämnes-/didaktiken som betonas i svenska och nordiska studier. Med tanke på att nordiska förskolor har likartade målstyrningssystem är det också lättare att anknyta till, översätta och använda resultat från nordisk didaktisk forskning än från utomnordiska studier. I en norsk studie konstateras exempelvis att det framträder ett avståndstagande från undervisningsbegreppet hos intervjuade barnehagelärare. Författarna menar att dominerande diskurser om 
barncentrerad verksamhet underminerar förskollärares betydelse som aktiva aktörer i förhållande till barns lärande (Hammer, 2012). Ett senare exempel från norsk barnehage tyder på att lärarna fortsatt inte använder undervisningsbegreppet i sin yrkesutövning (Sæbbe \& Pramling Samuelsson, 2017). Detta är ett tema som också återkommer i svenska studier (t.ex. Doverborg, Pramling \& Pramling Samuelsson, 2013; Jonsson, Williams \& Pramling Samuelsson, 2017; Rosenqvist, 2000; Vallberg Roth, 2018). Avståndstagandet visar sig dessutom i Skolinspektionens (2016) rapport, vilket exemplifieras i följande utsaga: "många fjärmar sig från att använda just begreppet undervisning" (s. 6).

Ett likartat avståndstagande och fjärmande tycks också gälla begreppet omsorg (Halldén, 2001, 2007, 2009; Löfdahl \& Folke-Fichtelius, 2015). Halldén (2001) framhåller att forskare "försökt att lansera "educare" som ett nytt engelskt begrepp just för att föra tanken mot en helhetssyn på omsorg och lärande. Men fortfarande dominerar skillnaden mellan dessa aspekter" (s. 39). I Josefson (2018) förs i avsnittet "Omsorg i måldokumenten - ett helhetsperspektiv?" (s. 18-25) ett resonemang kring begreppet helhet, men utan referens till undervisning. Josefson hänvisar till Lindgren (2006), Hammarström-Lewenhagen (2013) samt Thelin (2013), som på olika sätt belyser begreppet "helhet" i förhållande till omsorg och lärande. När det gäller omsorg är det, enligt Josefson (2018), allt fler studier som betonat frågor om omsorg, ansvar och etik. Josefson studerar omsorgens begreppsliga och praktiska innebörder i ett närhetsetiskt perspektiv. "Närhetsetiken betecknas som en erfarenhetsbaserad etik som utgår från mellanmänskliga praktiker" (Josefson, 2018, s. 7). Materialet är $\mathrm{i}$ tid genererat före införandet av undervisning $\mathrm{i}$ styrdokument för skolformen förskola, vilket kan ha påverkat utfallet då ordet undervisning inte är påfallande i de empiriska exemplen. Vidare exempel på studier där omsorg och lärande flätas samman i det vardagliga samspelet mellan pedagoger och barn, framhålls i Dalgrens avhandling (2017) som bygger på videoinspelningar från tre förskolor.

\section{Teoretiska perspektiv i tidigare forskning om undervisning i förskola - "lärifierad didaktik"}

I en inventering av forskning om undervisning i förskola i Sverige framträder en variation av teoretiska ingångar (Vallberg Roth, 2018). Ett påtagligt perspektiv på undervisning i förskola är didaktik (t.ex. Botö, Lantz-Andersson \& Wallerstedt, 2017; Doverborg, Pramling \& Pramling Samuelsson, 2013; Harju-Luukkainen \& Kultti, 2017; Hedefalk, 2014; Rosenqvist, 2000). I skandinaviska studier som fokuserar undervisning framträder utvecklingspedagogiskt perspektiv (t.ex. Björklund \& Ahlskog-Björkman, 2017; Doverborg, Pramling \& Pramling Samuelsson, 2013; Jonsson, Williams \& Pramling Samuelsson, 2017), som inkluderar sociokulturell teoribildning (t.ex. Melker, Mellgren \& Pramling Samuelsson, 2018; Sæbbe \& Pramling 
Samuelsson, 2017). Sedan finns studier med variationsteoretiskt perspektiv (t.ex. Gustavsson \& Thulin, 2017; Holmqvist Olander, 2013; Ljung-Djärf, Magnusson \& Peterson, 2014; Marton, 2015) och pragmatiskt perspektiv på undervisning (t.ex. Hedefalk, 2014). Med poststrukturell och postkonstruktionistisk ingång hamnar lärande i sociomateriella relationer i förgrunden (t.ex. Dahlberg \& Elfström, 2014; Lenz Taguchi, 2010/2012; Palmer, 2010; Palmer, Unga \& Hultman, 2017). Det finns också studier med posthumanistisk ingång där undervisningsbegreppet fokuseras (t.ex. Areljung, 2017). Vidare föreligger ett underskott av didaktisk forskning som bygger broar till ledarskap och organisation och som flyttar fokus från "lärande organisationer" till "undervisande organisationer" (jfr Uljens \& Ylimaki, 2017).

Innebörden av undervisning i förskola skiftar beroende på vilka teoretiska perspektiv och ingångar som används. De (meta)teoretiska ingångar som opererar i studierna har, som tidigare berörts, varit mer inriktade på lärande än på undervisning. Vi har till exempel sociokulturella perspektiv med inriktning på "situerat lärande" och variationsteori med "Learning study" som är inriktad på intentionellt lärande. Vidare har vi exempelvis pragmatiskt perspektiv med inriktning mot "reflektivt lärande" och postkonstruktionism med "rhizomatiskt lärande" (Vallberg Roth, 2018). Därmed framträder något av en "lärifierad didaktik" (a.a.).

Lärifierad didaktik kan kopplas till Biestas (2017) begrepp "lärifiering", som åsyftar det förändrade språkbruket med inriktning på "lärande" och "de lärande" (se vidare under rubriken "Lärifiering"). Fokus på lärande är givetvis inte enbart problematiskt. Tvärtom kan lärandeinriktade studier exempelvis bidra till värdefull kunskap om barns lärande i olika situationer och relationer såväl $i$ som utanför utbildningsinstitutioner. Inte sällan är det då barn och barns lärande i miljön och verksamheten som dokumenteras och det kan handla om hur lärare följer och stödjer barnens intressen, egna ansträngningar och lärandeprocesser. Då hamnar lärare i undervisning inte i förgrunden, på samma sätt som "de lärande", i dokumentation och teoribildning (jfr Biesta, 2017; Hammer, 2012; Lindgren, 2016). Studier om lärande behöver inte fokusera relationen mellan någon som undervisar någon om något, utan kan koncentrera sig på lärande och de som lär i miljöer och relationer. Utan att förringa studiernas värde och behov vill vi också framhålla behov av alternativ till lärandefokuserad forskning och lärifierad didaktik. Alternativ kan vara studier utifrån en mer undervisningsinriktad didaktik.

\section{Teoretiska perspektiv i forskning om omsorg, lek och undervisning i förskola}

I en kunskapsöversikt om undervisning i förskola (Sheridan \& Williams, 2018) belyses undervisning i relation till omsorg och lek utifrån olika teoretiska perspektiv. Björklund och Pramling Samuelsson (2018) beskriver en lekbaserad förskolepedagogik i vilken omsorg och lärande ses som 
dimensioner i undervisningen. Författarna utgår från utvecklingspedagogik, variationsteoretiska antaganden och sociokulturella perspektiv. Vidare presenteras ett kapitel med inriktning på förskolans uppdrag där omsorgsfull och lekfull utbildning och undervisning bildar en helhet (Eidevald, Engdahl, Frankenberg, Lenz Taguchi \& Palmer, 2018). Författarna belyser undervisning som en omsorgsfull och lekfull undervisning $i$ vilken förskollärare, kamrater och miljö stöttar barns utveckling och lärande. Teoretiskt utgår författarna dels från multidisciplinär forskning om barns utveckling och lärande inom ramen för utvecklingsvetenskap ("developmental science"), dels från begreppet "samaktivt stöttande" (t.ex. Mascolo \& Fischer, 2015). Kunskapsöversiktens sammanfattning avslutas med att det finns behov av mer forskning på området och att forskning med fördel kan bedrivas i samverkan mellan förskollärare och forskare (Sheridan \& Williams, 2018).

\section{Föreliggande studie $i$ relation till underskott $i$ tidigare forskning}

Grunden i föreliggande artikel kan ses som alternativ till lärifierad didaktik. Det rör sig om en undervisningsinriktad didaktik i samverkan - en didaktik som tonar fram och är under utveckling i samverkansprojektet (se vidare under rubriken "Metod, material och analys i didaktiskt perspektiv").

I exempel från undervisningsstudier som är inriktade på grund- och gymnasieskola framhävs att det finns "faktiskt ingen teori som kan innesluta den totala undervisningssituationen" (Arfwedson, 1998, s. 131). I sammanhanget framträder behov av att forskning och teoribildning inriktas på undervisning $\mathrm{i}$ förskola, med öppenhet för att också flera (meta)teoretiska ingångar kan inkluderas. Det kan handla om att belysa undervisning och didaktik i relation till omsorg och lärande.

Det föreligger också behov av forskning som studerar undervisning $i$ förskola $\mathrm{i}$ mer omfattande studier. I det här sammanhanget belyser föreliggande studie, som en del i samverkansprojektet (se not 1), ett stort antal förskolor i tio kommuner. I nästa avsnitt fokuseras tidigare forskning rörande centrala begrepp $i$ artikeln.

\section{Begreppen omsorg, lärande och undervisning - nedslag i tidigare forskning}

För att förstå helheten behöver vi identifiera delarna som $\mathrm{i}$ artikeln är inriktade på omsorg och lärande i undervisning. I relation till syftet gör vi några nedslag rörande dessa begrepp i tidigare forskning. Även om vi inleder med begreppen omsorg och lärande, så är det begreppet undervisning som är i förgrunden $i$ artikeln. Och det är undervisning som huvudbegrepp $i$ relation till omsorg och lärande som studeras, vilket kan ses som alternativ till tidigare studier där omsorg och/eller lärande varit i förgrunden. 


\section{Omsorg}

"Omsorg" kan tolkas i meningen att ta hand om och ansvara för någons trygghet, säkerhet, integritet och välbefinnande. Omsorg i institutionella sammanhang kan avse en relation mellan omsorgsgivare och omsorgstagare (Davies, 1996; Noddings, 1984, 2012). Begreppet kan, enligt Davies och Noddings, stå för en etisk relation som refererar till att om någon behöver mig, vänder jag mig inte från denne. Omsorg rör sig om en ömsesidig relation och process som inbegriper både den som ger omsorg och den andres svar på omsorgen. Grunden för omsorg kan då vara att vi ser och/eller känner igen och återkopplar på andras behov i relation till miljö och sammanhang. Davies (1996) framhåller både socioemotionella och fysiska dimensioner i omsorg, såsom att sörja för fysiska och kroppsliga behov som att byta blöja, kroppslig närhet, hjälpa till med på- och avklädning, och behov av psykologisk och social karaktär som att trösta, lyssna, ge råd och hålla sällskap i samvaro.

Omsorg upptar en ökad del av förskolans vardag, beroende på att andelen yngre barn ökar (jfr Löfdahl \& Folke Fichtelius, 2015). Omsorgen är dock inte tydlig i dokumentation och utvärderingar (a.a.). Undervisning kan i förhållande till unika barns och barngruppers behov av omsorg prövas i relation till "Att behandla alla lika olika" (Josefson, 2018, s. 160). Josefson gör en bestämning av omsorg i förskola enligt följande: "Att synliggöra omsorgens innebörder i förskolan innebär att synliggöra förskolan som en mellanmänsklig och empatisk praktik, som bland annat speglar förskolepedagogernas erfarenheter och föreställningar om ansvar och omsorg" (2018, s. 153).

Sammantaget kan omsorg kopplas till "tanke, känsla och handling" och till "kropp, material och miljö". Så omsorgsrelationer kan också inkludera omsorg för miljö och materiella ting i sociomateriella relationer, inklusive djur, teknik och natur (Vallberg Roth, 2017).

\section{Lärande}

Lärande "är varje process som hos levande organismer leder till varaktig kapacitetsförändring som inte bara beror på glömska, biologisk mognad eller åldrande" (Illeris, 2015, s. 18). Illeris formulerar lärande som både en inre och samspelsmässig process. Samlärande är ett begrepp som betonar lärande mellan barn, när barn lär av varandra (t.ex. Williams, Sheridan \& Pramling Samuelsson, 2001). Illeris refererar (2015) också till neurovetenskap som han menar gett väsentliga bidrag till hur minne, tänkande och lärande fungerar. Vidare exempel är "rhizomatiskt" och transdisciplinärt lärande (t.ex. Lenz Taguchi, 2010/2012; Palmer, 2010, 2011). Rhizomatiskt lärande följer, likt rhizom (rotnätverk som kvickrotens eller svampmycel), "inte en linjär och på förhand utstakad väg, utan går lite hit och dit i oförutsägbara banor" (Skolverket, 2012, s. 27). Transdisciplinärt lärande kan innebära att sammanföra olika discipliner och lära i nya överskridande ämnen. I ett projekt 
studeras socioemotionellt, materiellt och digitalt lärande i en interdisciplinär studie som involverar pedagogik, didaktik, lingvistik, psykologi och neurovetenskap (Lenz Taguchi \& Palmer, 2017).

\section{Undervisning}

Undervisning är ett begrepp som skiljer sig från begreppen lärande (t.ex. Illeris, 2015) och omsorg (t.ex. Davies, 1996; Noddings, 2012). Undervisning förutsätter, med referens till skollagen, en relation mellan en lärare som undervisar någon (t.ex. ett barn), om något, exempelvis ett stoff (jfr Biesta, 2017). Det är inte samma sak för omsorg och lärande. Lärande och omsorg förutsätter inte en lärare. Barn kan lära och vara $\mathrm{i}$ omsorgsrelationer också utanför förskola och utbildningsinstitutioner. Vidare är undervisning, med koppling till skollagen, målstyrd och syftar till barns utveckling och lärande. Omsorg kan också syfta till utveckling och lärande men behöver inte göra det, utan kan istället exempelvis syfta till vila, samvaro, trygghet och rekreation. Samtidigt som det framträder en åtskillnad mellan begreppen visar resultaten i artikeln också spår av att undervisning är ett begrepp där tecken på barns lärande och omsorg kan flätas samman på olika sätt (jfr Vallberg Roth \& Tallberg Broman, 2018). Omsorg och lärande förutsätter i sig inte en lärarperson, men omsorg kan förstås som förutsättning för lärande som i sin tur skulle kunna förstås som ett möjlighetsvillkor för undervisning i förskolan.

Biesta (2017) tar avstånd från såväl barncentrerad som läroplanscentrerad undervisning och framhåller ett alternativ, en "världscentrerad undervisning". Det handlar om att sätta barnet och världen i förbindelse med varandra. Med världen avser Biesta andra människor, djur, växter, idéer, böcker, teorier, litteratur, med mera (Biesta, 2017; Olsen, 2018). Att leva ett liv innebär att leva med andra människor i en fysisk miljö. Poängen med undervisning är att visa barn möjligheter $\mathrm{i}$ världen som ligger bortom det som barnen har erfarenhet av och kan föreställa sig. Barnen kan svårligen visa intresse för och vilja lära sig något det inte har kännedom om och vet existerar. Läraren kan tillföra något nytt och öppna världen för barnen, så att de kan leva $\mathrm{i}$ världen och inte bara leva i sin egen värld (a.a.).

\section{METOD, MATERIAL OCH ANALYS I DIDAKTISKT PERSPEKTIV}

Samverkansforskningens design utgår från en kvalitativ ansats som utgörs av prövande serier av teoriinformerade undervisningsupplägg (se not 1). Uppläggen studeras med utgångspunkt $\mathrm{i}$ medverkandes genererade samplaneringar, deras observationer av undervisning som kan vara filmade, samt medverkandes samvärderingar (se nedanstående materialbeskrivning). I artikeln använder vi exempel från projektmaterial som genererades vid ett didaktiskt informerat undervisningsupplägg år 2016 (se not 1). Didaktiskt 
perspektiv, med anknytning till "undervisningsinriktad didaktik" som nämndes $\mathrm{i}$ avsnittet om tidigare forskning, ses som kunskapsbas för undervisning och är genomgripande i undervisningsupplägg och analys.

\section{Didaktiskt perspektiv}

Didaktik fokuserar relationer mellan lärare-barn-innehåll - med andra ord en teori om att undervisa (t.ex. Comenius, 1632/1989; Uljens, 1997). Ordet didaktik kan förklaras som "konsten att peka ut något för någon" (Doverborg, Pramling \& Pramling Samuelsson, 2013, s. 7) - helt enkelt att något är under visning.

Didaktik kan tolkas vara lärares professionsvetenskap (Ingerman \& Wickman, 2015), vilken kan stödja förskollärare att göra informerade didaktiska val i relation till undervisning av innehållet. Vidare har didaktik både en praktik- och teorinära sida som kan kopplas till vetenskaplig grund och beprövad erfarenhet:

Didaktik är å ena sidan ett vetenskapligt område som har ett fokus mot undervisning, men som också inbegriper andra vetenskapliga områden/.../ å andra sidan är allmän didaktik också ett praktiskt kunnande, en handlingsberedskap, som bygger på beprövad erfarenhet. (Brante, 2016, s. 57)

I artikeln är undervisningsinriktad och kritisk-reflektiv didaktik vägledande i förhållande till en oviss framtid (jfr Biesta, 2017; Brante, 2016; Broström, 2012; Klafki, 1997). Konkret har vi i forskningsfrågorna exempelvis bytt ut det modala hjälpverbet "ska" till "kan". I didaktiska frågor anknyter "ska" mer till traditionellt normativ och preskriptiv didaktik, medan vi kopplar "kan" till kritisk-reflektiv didaktik. "Kan" öppnar för att det kan finnas alternativ till de val som görs och vi gör inga anspråk på att en gång för alla slå fast "vad som ska undervisas" eller "vad som kännetecknar...", utan är inriktade på "vad som kan känneteckna..." och så vidare. Förskolans målstyrning med mål att sträva mot, med förutbestämd riktning utan förutbestämt slutmål och utan kunskapskrav som "ska" uppnås på individnivå, kan också tolkas vara förenlig med denna inriktning.

Kritisk-reflektiv didaktik strävar efter att ge stöd för kritisk reflektion genom alternativa redskap - poängen är att öppna för något alternativt. I artikeln öppnas för "flerstämmig undervisning" som kan inrymma didaktisk (o)takt. Med andra ord kan undervisningsinriktad och kritisk-reflektiv didaktik som utmynnar i begreppen "flerstämmig undervisning" och "didaktisk (o)takt" ses som alternativ till lärifierad didaktik där dessa begrepp inte använts (se vidare under rubriken "Samlad analys - begreppsprövande fokus"). 
Med flerstämmig avses flera röster i många stämmor, vilket kan översättas till flera infallsvinklar och variation av närmanden, i motsats till ensidigt närmande som exempelvis kan vara uteslutande inriktat på lärandesidan av didaktik eller på konstruktionism som uttrycks i termer av att det finns "inget rätt eller fel" (jfr Vallberg Roth, 2018). Den norska språkvetaren Dysthe (1993) lanserade "det flerstämmiga klassrummet", med framträdande inspiration från den ryske filosofen, och litteraturteoretikern Bakhtin och hans medarbetares arbeten. Sociolingvistisk och sociokulturell grund är framträdande. Begreppet flerstämmig undervisning har inspirerats av Dysthe samtidigt som ett mer expansivt närmande utprövas som avser att inrymma flera vetenskapliga grunder och beprövade erfarenheter. Sammantaget kan flerstämmig undervisning prövas som redskap för kritisk reflektion, vilket kan inkludera olika aktörers perspektiv (versioner), vetenskapliga grunder och beprövade erfarenheter (se vidare under rubriken "Flerstämmig undervisning").

\section{Material}

Materialet inkluderar totalt 349 skriftliga dokument och 63 filmtimmar. Medverkande förskollärare har planerat, filmat/dokumenterat genomförandet och följt upp undervisningen. Deltagarna genererar empiri utan forskares närvaro i praktiken. Skriftliga dokument innefattar 177 planeringar och 172 uppföljningar av undervisning. De skriftliga dokumenten omfattar totalt cirka 80000 ord. Materialet kommer från 121 förskolor/avdelningar i tio kommuner. Analysenheten på datanivå utgörs av ord-data och audiovisuella data.

\section{Etiska överväganden}

I projektet följs forskningsetiska principer enligt humanistisk-samhällsvetenskaplig forskning (Vetenskapsrådet, 2017). Det innebär bland annat att samtliga deltagare ska informeras och tillfrågas om deltagande enligt informationskravet. Allt deltagande är helt frivilligt och kan avbrytas när som helst utan angivande av skäl för detta, enligt samtyckeskravet. Alla deltagare i programmet har informerats och fått möjlighet att ge sitt samtycke.

Studien genomförs genom registrerade aktiviteter, exempelvis genom ljudupptagning, anteckningar och film. Det är professionellt verksamma i förskolan som genomför och registrerar aktiviteterna. Registrerade uppgifter behandlas konfidentiellt och förvaras på en plattform (Box) som är tillgänglig för forskare i projektet. En deltagare per förskola/avdelning utses för att lägga upp material på plattformen. Den utsedde har enbart tillgång till det material de själva lägger upp. All dataproduktion är kodad efter ett av oss bestämt system med fingerade namn, och kodnyckel förvaras inlåst $\mathrm{i}$ fakultetens arkivskåp, enligt konfidentialitetskravet. Barn i unga åldrar medverkar i studien och vårdnadshavarnas samtycke är en förutsättning. Särskilt ansvar för barns 
integritet vilar på forskarna. Med koppling till nyttjandekravet används genererade uppgifter för forskningsändamål och avrapporteras av forskarna som strävar efter att enskilda personer inte kan identifieras av utomstående.

\section{Abduktiv analys}

Utifrån metodologisk synvinkel kan analysen referera till så kallad abduktiv analysprocess. Med abduktiv analysprocess avses att en alternering sker mellan teoriladdad empiri och empiriladdad teori, varvid båda successivt omtolkas i skenet av varandra (Alvesson \& Sköldberg, 2008; Peirce, 1903/1990; Tavory \& Timmermans, 2014).

Analysen pendlar mellan empirinära, öppen läsning och teorinära spårning. Mer konkret handlar analysen om att identifiera spår och mönster i materialet i förhållande till studiens syfte och frågor. Didaktiska frågor utgör både redskap i praktikerna och analysfrågor i vår studie. Analysen kan då beskrivas enligt följande tolkningsled som i praktiken är mer sammanflätade än vad nedanstående punktlista ger sken av (jfr Alvesson \& Sköldberg, 2008; Rapley, 2011; Vallberg Roth, 2018):

\section{Empirinära analysled}

- Nära bearbetning - vi läser, lyssnar och tittar igenom materialet flera gånger och partiellt transkriberar (se transkriptionsnyckel i not 2) samt markerar framträdande ord.

- Analys med kvantitativa inslag i texter - framträdande ords frekvenser räknas med hjälp av "Find-funktionen" i Word redovisas i stapeldiagram (se Figur 1). Ordfrekvensanalysen kan ses som ett kvantitativt inslag i den kvalitativa bearbetningen av data. Det rör sig inte om en kvantitativ och statistisk analys som gör anspråk på att alla och en var av orden i materialet är kvantifierade och statistiskt bearbetade. Poängen med det kvantitativa inslaget är att stabilisera analysen av det omfattande materialet och förhoppningsvis reducera felkällor och övertolkningar - som exempelvis konfirmeringsbias (att selektivt uppmärksamma data som bekräftar förutfattade uppfattningar).

- Utmärkande spår - det vill säga analys av hur ord i text och transkriptioner samverkar och förstärker varandra i sitt sammanhang (se transkriptionsnyckel²) - spår av meningsbärande enheter identifieras, grupperas, benämns och exemplifieras i underrubriker (se t.ex. "Utmärkande spår med omsorgsinflätad undervisning musik i fokus"). 


\section{Teorinära analysled}

- I det teorinära analysledet kopplas utmärkande spår till tidigare forskning. Problematisering och intertextuell analys genomförs där empiriska och vetenskapliga texter relateras till varandra (se t.ex. "Problematisering av lärande och omsorg i relation till undervisning").

- Samlad analys genomförs i relation till forskningsfrågor som utmynnar i ett begreppsprövande fokus utifrån studiens didaktiska grund (se begreppen "didaktisk (o)takt" och "flerstämmig undervisning" under rubriken "Samlad analys - begreppsprövande fokus").

Utifrån syftet är det förskollärarnas skriftliga beskrivningar och samhandlingar som framträder i det filmade materialet som analyseras och tolkas till att kunna känneteckna undervisning.

\section{Urval av exempel, citat och utdrag frain transkriptioner}

Urval av material för analys bygger på de exempel som deltagarna valt att lägga upp på plattformen "Box". Grunden för våra val av citat och utdrag från transkriptioner $i$ artikeln görs i förhållande till att de exemplifierar variationen av spår i materialet på minst skrymmande och samtidigt tydliga sätt $i$ förhållande till syfte och frågor. I följande avsnitt presenteras resultatet.

\section{RESULTAT}

I resultatdelen redovisas först analysen för frågan om vad som kan känneteckna undervisning i relation till omsorg och lärande i förskollärares texter och dokumenterade samhandlingar i förskola. Därefter presenteras analysen för frågan om vilka spår av didaktiska frågor som kan uttolkas, $i$ relation till undervisning, omsorg och lärande, i förskollärares texter och dokumenterade samhandlingar i förskola.

\section{Vad kan känneteckna undervisning i relation till omsorg och lärande i förskola?}

I det här avsnittet belyser vi vad som kan känneteckna undervisnings i relation till omsorg och lärande $\mathrm{i}$ förskollärares texter och dokumenterade samhandlingar i förskola. Vi är inriktade på att studera hur den så kallade helheten av omsorg och lärande i undervisning framträder i materialet. Vi följer våra analyssteg (se "Abduktiv analys") och börjar med exempel på kvantitativa inslag där vi först fokuserar ordfrekvenser i det skriftliga materialet. Därefter går vi vidare med utmärkande spår och problematiserade exempel. 
Vaga spair av omsory och trygghet $i$ skeriftligt material - ordfrekvenser

I det skriftliga materialet med planering och uppföljning av undervisning framträder vaga spår av omsorg och trygghet, medan begrepp som barn och lärande är mer frekventa. I nedanstående diagram ges exempel på empirinära analysled med kvantitativt inslag:

Figur 1: Ordfrekvenser i skriftligt material

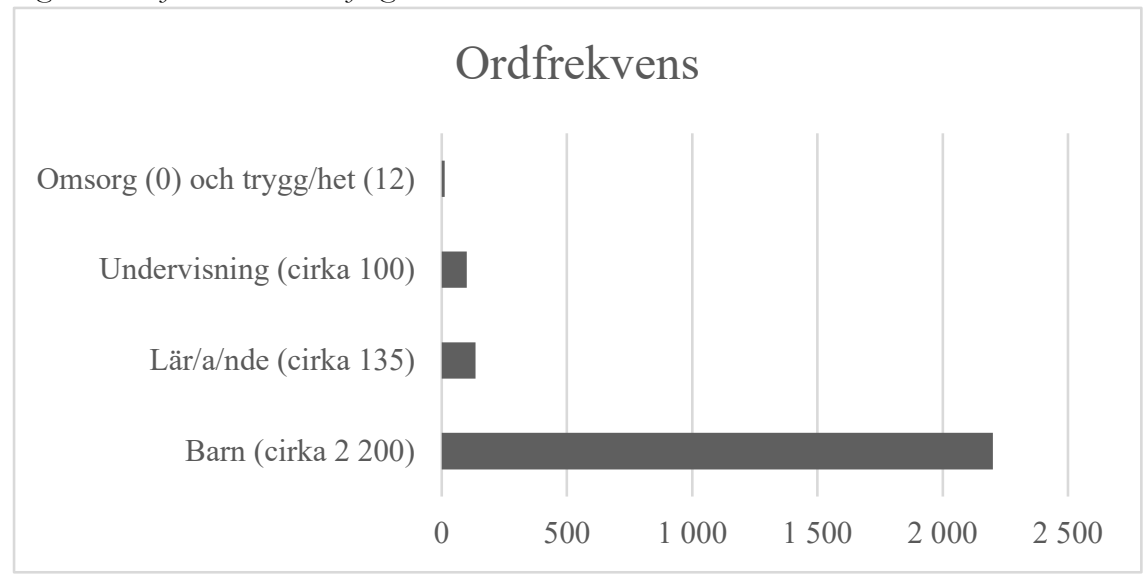

Diagrammet över ordfrekvenser i det skriftliga materialet visar höga frekvenser av ordet barn (barn nämns cirka 2200 gånger). "Lär/a/nde" är också relativt frekvent förekommande (cirka 135 gånger). "Undervisning" nämns vid något färre tillfällen (cirka 100 gånger). Det är förhållandevis få eller inga träffar på "omsorg" (0) och "trygg/het" (12) i materialet. Därmed kan den så kallade helheten $i$ det skriftliga materialet snarare tolkas vara dominerad av lärande än vara fördelad i ungefär lika delar omsorg och lärande. Detta kan jämföras med frekvenser av orden lärande, omsorg och trygghet $\mathrm{i}$ läroplanen (SKOLFS 1998:16, som gällde för tiden då materialet genererades). I läroplanen nämns "lär/a/nde" också mer frekvent (cirka 50) än "omsorg" (cirka 10) och "trygg/het" (7). Undervisning nämns inte alls som begrepp i läroplanen som reviderades 2016 (SKOLFS 1998:16). Vi kan fråga oss om det är den här relationen mellan begreppen som avses med "helhet" i styrdokumenten, det vill säga en helhet med mer lärande än omsorg och trygghet. Möjligen kan "lärifierad helhet" prövas som uttryck för detta kvantitativa utfall som inkluderar relationer mellan delarna, omsorg, trygghet och lärande, i helheten. Till skillnad från det skriftliga materialet framträder påtagliga omsorgsdimensioner i det filmade materialet, vilket vi övergår till i nästa avsnitt. 


\section{Utmärkande spår med omsorgsinflätad undervisning - musik i fokus}

I de filmade samhandlingarna finns påtagliga omsorgsdimensioner som är inflätade i undervisningsstunderna. Exempel på omsorgsdimensioner som framträder kan tolkas vara inriktade på både socioemotionella och fysiska dimensioner. Här följer ett exempel där förskollärare genomför undervisning i musik under drygt två minuter med några 2-åringar. Undervisningsstunden genomförs i ett innerum med öppen golvyta som är bekant för barnen. En förskollärare samhandlar med barnen sittande med knäna under sig på golvet i mitten av rummet. En pedagog observerar och registrerar genom film, samt ansvarar för teknik och sätter på musiken. Genom att introducera ett stycke klassisk musik, "I bergakungens sal" av Edvard Grieg, riktar förskolläraren barnens uppmärksamhet mot något som är mindre bekant för dem. Barnen får tillfälle att komma i kontakt med olika dimensioner av musik som dynamik och tempo. Filmen, som transkriberats nedan, slussar oss rakt in $\mathrm{i}$ musikstunden, med barn, förskollärare och klassisk musik som huvudaktörer i samhandlingen:

Klassisk musik spelas och fyra barn ömsom står ömsom rör sig nära förskolläraren, som återkopplar genom att möta och tona in barnens blickar, behov av närhet och tal i mötet med något för dem mindre bekant.

Barnen har ett koncentrerat och lite frågande, för ett barn på gränsen till osäkert, uttryck i ansiktena. De kan tolkas erfara för dem mindre bekanta ljud som de intensivt försöker identifiera och skapa mening omkring. Förskolläraren sitter med knäna under sig på golvet och två av barnen håller förskolläraren i händerna. Efter en kort stund vänder sig ett av barnen med kroppen och blicken till förskolläraren och prövar i tal vad hon har identifierat för ljud.

\section{B1: Musik}

Förskolläraren återkopplar genom sitt kroppsspråk, hon vänder sin kropp och sin blick mot barnet samtidigt som hon nickar och ler. Parallellt sker återkoppling också genom talspråk, då hon förstärker och speglar det barnet sagt.

F: Ja, det är musik.

Ett annat barn pekar mot högtalaren och säger samtidigt:

B2: Musiken 
Förskolläraren återkopplar genom att vända sig med kropp och blick till det andra barnet och nickar samtidigt som hon upprepar och förstärker det barnet sagt och gör ett tillägg om varifrån ljudet kommer.

F: Ja, kommer musiken där från högtalaren.

Genom tillägget vidgas perspektivet och ett nytt begrepp tillförs som sätter in det barnet kommunicerat $\mathrm{i}$ ett större sammanhang i relationen ljudmusik-högtalare.

Barnen fortsätter att lyssna intensivt, rör sig försiktigt i takt och flyttar sig lite närmare förskolläraren när musikljudet tilltar i styrka, dynamiken blir starkare och tempot snabbare. Förskolläraren ler lugnande och sitter och nickar i takt med musiken och möter barnens blickar och liksom öppnar och tillgängliggör sitt knä, håller barnen som vill i händerna och tonar in barn som behöver närhet. Så plötsligt slutar musiken och ett av barnen som identifierat ljudflödet som musik säger:

B1: Slut!

Förskolläraren tonar återigen in barnet och återkopplar genom att förstärka och spegla det barnet sagt.

F: Ja, nu är musiken slut. (Transkription av filmat material, 2016)

I exemplet framträder tecken på barns lärande i musik i en omsorgsinflätad undervisning. Omsorgsdimensioner är påtagligt närvarande då förskolläraren exempelvis möter barnens blickar och behov av kroppslig närhet genom att hålla barnen som vill $\mathrm{i}$ händerna och genom förstärkande och speglande samtal. Omsorg kan då handla om att bry sig om och sörja för att möta barns sammanflätade socioemotionella, kroppsliga och kognitiva behov.

\section{Problematisering av undervisning i relation till lärande och omsorg}

Även om omsorgsdimensioner kan vara inflätade i undervisning vill vi i sammanhanget också framhålla exempel på åtskillnad mellan begreppen. Ett exempel på åtskillnad är att medan undervisning, enligt styrdokument, syftar till lärande behöver inte omsorg och trygghet syfta till lärande utan kan kopplas till samvaro, vila och rekreation. Och det kan exemplifieras med när barnen sover tryggt på förskolan.

För att tydliggöra gränser mellan begreppen problematiserar vi utifrån några vidare exempel. Poängen är att vända och vrida på vad begreppen kan innebära. Barns lärande och omsorg förutsätter, som nämnts, inte lärare. Undervisning förutsätter lärare (SFS 2010:800) och bygger på relation mellan någon som undervisar någon om något (jfr Biesta, 2011, 2017). Undervisning 
framträder därigenom som ett relationellt begrepp som handlar om att rikta någons uppmärksamhet mot något. På så sätt menar Biesta att undervisning skiljer sig från begreppet lärande som inte förutsätter lärare. Vidare kan undervisning ses som lärares professionella yrkesutövning och innebära en betoning på lärares ledarskap och på lärare som tillför och möjliggör något nytt (Biesta, 2017).

\section{"Lärifiering"}

Biesta (2011) poängterar att lärande i grunden är en individualistisk term som åsyftar det människor gör som individer. Lärande kan tolkas stå i kontrast till begreppet undervisning som anger en relation mellan någon som undervisar någon annan. "Lärifiering" (Biesta, 2011, s. 23) kan relateras till ökningen av begreppet lärande i bindande styrdokument (Vallberg Roth, 2018). Att sätta lärande och den lärande i centrum innebär, enligt Biesta (2011), att fokus riktas mot

- den lärande/barnet som förväntas vara aktiva och mer självständiga i sitt kunskapsbyggande

- $\quad$ och lärarens roll blir mer följande och stödjande av de lärandes egna ansträngningar att skaffa, använda och skapa kunskap

- vilar i strömningar som ser individen som ansvarig för sitt eget (livslånga) lärande - i grunden en individualistisk term som åsyftar det människor gör som individer (jfr Biesta, 2011)

Vidare ifrågasätter Andersen Østergaard, Hjort och Skytthe Kaarsberg Schmidt (2008) om det ens är möjligt att registrera och dokumentera lärande. Författarna hävdar att lärande och lärprocesser är otillgängliga, ej möjliga att iaktta och immateriella, såsom idéer, lukter och smaker. Lärande kan i den meningen, enligt författarna, inte registreras. Författarna fokuserar inte neurovetenskapens möjligheter i sammanhanget. Notera att vi i artikeln använder uttrycket "tecken på lärande" och att lärare kan registrera och tolka tecken på lärande.

\section{Leder undervisning alltid till lärande?}

Ordet lärande kan också användas som liktydigt med undervisning (Vallberg Roth, 2018). Då identifieras ingen skillnad mellan det som läraren undervisar och det som barnet lär sig (Illeris, 2015). I praktiken kan undervisning genomföras utan att det sker något avsett lärande. "Det finns inget automatiskt samband mellan undervisning och lärande" (Illeris, 2015, s. 16). Tecken på att undervisning möjligen inte lett till lärande kan vi spåra och uttolka i följande utsaga från ett förskolebarn $i$ det första undervisningsupplägget: "Jag visste redan det" (utsaga från film i UndiF- 
materialet, 2016). Nu övergår vi till att fokusera spår av didaktiska frågor i relation till undervisning, omsorg och lärande.

\section{Vilka spår av didaktiska frågor kan uttolkas?}

I avsnittet behandlar vi forskningsfrågan "Vilka spår av didaktiska frågor kan uttolkas, i relation till undervisning, omsorg och lärande, i förskollärares texter och dokumenterade samhandlingar i förskola?”. Vi börjar med utmärkande spår som sedan leder över i teorinära analysled kopplade till didaktik.

\section{Didaktisk a frågor relaterat till omsorg - skriftligt material}

Det finns, som tidigare nämnts, få explicita spår av omsorg och trygghet (se Figur 1) i det skriftliga materialet. I planeringarna och uppföljningarna av undervisning framträder några spår av didaktiska frågor som inrymmer explicita omsorgsdimensioner inriktade på trygghet, enligt följande:

Vad? "Sångerna ska vara samma som innan, barnen behöver något välkänt som får dom att känna sig trygga.” (Planering, 2016)

"Populärmusiken är ett mer naturligt inslag i barnens omgivning vilket därför känns tryggare." (Uppföljning, 2016)

Hur? "Ville att barnen skulle börja som vi brukar i samlingen för att känna sig trygga." (Uppföljning, 2016)

"Undervisningsmomentet bör genomföras ett antal gånger. Upprepning skapar igenkännande som också blir en trygghet.” (Uppföljning, 2016)

Vem/vilka? "Två barn sökte tryggheten hos mig. Det var en ovan situation för barnen.” (Uppföljning, 2016)

Var? "Rummet var bra, ramar in aktiviteten, skapar gemenskap och trygghet." (Uppföljning, 2016)

Till skillnad från fåtalet explicita spår av orden omsorg och trygg/het framträder det påtagliga explicita spår av "lär/a/nde" i det skriftliga materialet i relation till didaktiska frågor.

\section{Didaktiska frägor relaterat till lärande - skriftligt material}

Lärande är, som tidigare nämnts, ett relativt frekvent ord (se Figur 1) i det skriftliga materialet. I förhållande till de didaktiska frågorna tonar lärande företrädesvis fram i vad-frågan, men framträder även i andra didaktiska frågor, enligt följande exempel:

Vad? "Målet är att låta barnen få uppleva dynamiken i musiken och lära känna skillnaden på starkt och svagt genom röst (sång), instrument, rörelse och lyssnande." "Bergakungens sal." (Planering, 2016)

"Syftet med aktiviteten är att barnen ska få uppleva och lära sig om det inom-musikaliska området "dynamik". Det vill säga, när ljudet rör sig 
mellan t.ex. starkt och svagt eller högt och lågt. Vårt fokus kommer att ligga på motsatserna starkt/svagt. Genom att arbeta med dynamik kan barnen få en känsla för skillnader i musiken/ljudet.” (Planering, 2016)

"Genom sång, musik och rörelse lära känna olika tempo" (Planering, 2016)

Hur? "Vi ska lyssna och lära oss skillnaden mellan starka och svaga ljud från instrumenten.

Vi ska lära oss begreppen starkt, svagt och dynamiskt." (Planering, 2016)

"Alla barnen vill göra detta igen och vill lära sig mer om klassik musik. Vi har fortsatt." (Uppföljning, 2016)

"Vi sjöng sångerna vid flera olika tillfällen för att barnen skulle kunna lära sig sångerna. (Uppföljning, 2016)

Vem? "Förskolläraren som ska leda aktiviteten ser till att lära sig sången ordentligt i förväg" (Planering, 2016)

"Det var roligt att utmana mig själv och lära tillsammans med barnen." (Uppföljning, 2016)

Var? "Jag började i kapprummet, för att slippa konflikter i samlingsringen, och för att barnen skulle lära sig sången medan vi gick in.” (Uppföljning, 2016)

Ett sätt att beskriva musik som innehåll i undervisning i förskola är att lyfta fram det som Nielsen (2006) beskriver som musikens olika dimensioner. Två dimensioner som är framträdande i vad-frågan kopplat till lärande är inriktningen på dynamik och tempo i materialet (se vidare dimensioner $\mathrm{i}$ Holmberg \& Vallberg Roth, 2018). Det är intressant att relatera utfallet i det skriftliga materialet till läroplanen (SKOLFS 1998:16). I läroplanen nämns sång, musik och rörelse, men inte exempelvis innehållsdimensioner som dynamik och tempo. Sång och rörelse nämns i både material och läroplan, men att lära i förhållande till exempelvis instrumentspel, lyssnande och musikgenre (klassisk musik) som nämns i materialet, förekommer inte i läroplanen.

\section{Problematisering av "helheten" $i$ relation till didaktiska fragor}

För att återgå till ovanstående filmexempel med musik i fokus så kan helheten med omsorgsdimensioner och lärande i undervisning också problematiseras ur ett didaktiskt perspektiv (t.ex. Nielsen, 2006; Uljens, 1997). Tecken på lärande i undervisning kan då relateras till trygghet. Att lära kan innebära möjliggörande av möte med något som är mindre bekant för barnen, vilket innebär att undervisningen kan röra sig bortom en välbekant och trygg zon (jfr Biesta, 2017; Osberg \& Biesta, 2010). I ovanstående exempel kan den didaktiska vad-frågan och innehållet med den klassiska musiken, "I bergakungens sal" av Edvard Grieg, tolkas ligga bortom den trygga zonen. Tryggheten kan istället vara inflätad i den didaktiska hur-, vem- och varfrågan, som innebär att välkända lärare och barn (vem) lyssnar på musik i 
tryggt intonat genomförande (hur), i rum (var) som alla känner och är vana vid. Så i exemplet kan mötet med det obekanta innehållet, den klassiska musiken, tolkas vara grundad i en för barnen i övrigt tryggt intonad undervisningsstund. Att tona in kan avse en strävan att komma i harmoni med barnens känsloläge, att genom gradvis närmande komma på samma våglängd i en samstämmig känsloton.

I undervisningen kan didaktiska val med inflätade omsorgsdimensioner anpassas till unika barns och barngruppers behov. Det kan innebära att förskollärare i samhandling med barn i någon eller några didaktiska frågor rör sig bortom en trygg och välbekant zon för att öppna för lärandemöjligheter och möten med något nytt (Biesta, 2017). Andra exempel än det ovanstående med klassisk musik kan vara att innehållet med musiken är bekant, medan materialet kan vara obekant, exempelvis att spela till musiken med för barnen nya musikinstrument. Rummet och genomförandet kan vara nytt medan innehåll och aktörer kan vara bekanta och trygga: "Det var första gången de var med i ett rytmikpass i det rummet och upplevelsen var för dem ny" (skriftlig uppföljning av undervisning i materialet, 2016). Vidare kan exempelvis innehållet, materialet och rummet vara bekant medan någon aktör är obekant, om exempelvis en ny musikpedagog kommer på besök.

Sammantaget skulle det å ena sidan kunna bli okänsligt för barnens behov och innebära en för stor utmaning om undervisningen samtidigt och i relation till merparten av de didaktiska frågorna rörde sig bortom den trygga och välbekanta zonen. Det skulle till exempel kunna bli en för stor utmaning om innehåll, form, aktörer och rum samtidigt var nya för barnet eller barngruppen. $\AA$ andra sidan skulle det även kunna bli tråkigt om allt var tryggt, välbekant och fullt av omsorg. Ett konkret exempel på det senare är förskollärare som uttryckligen fokuserar ett bekant innehåll i undervisningen för att barnen ska känna sig trygga: "Sångerna ska vara samma som innan, barnen behöver något välkänt som får dom att känna sig trygga" (skriftlig planering i materialet, 2016). I uppföljningen efter undervisningen reflekterar förskollärarna över det bekanta innehållet och skriver om sina iakttagelser av barnen i gruppen: 'Tröttnar efter en stund. Är det tråkigt, för lätt, behövs det någon annan input?”. Ett annat exempel är inriktat på ett unikt barn och lyder: "Vi upplever att barnet lätt blir uttråkad - behöver utmaningar" (skriftlig uppföljning av undervisning i materialet, 2016).

Så undervisning kan i relation till omsorg prövas som begrepp där någon eller några av de didaktiska valen medför en rörelse som kan tänja, utmana och föra barns möjlighet till lärande bortom en alltigenom välbekant och trygg zon som är full av omsorg. I samverkansprojektet prövar vi begreppen omsorg och trygghet i förhållande till begreppen undervisning och lärande $i$ ett didaktiskt perspektiv. I det sammanhanget kan omsorg också vara ett objekt för lärande, exempelvis att barn lär sig att visa omsorg om andra och miljön. Det kan också innebära att läraren exempelvis tonar in och delar det 
känslomässiga läget vid tecken på att lärande kan kännas motigt och då uppmuntra ansträngningen: "Helt fantastiskt hur länge du funderade. Det gillar jag skarpt" (förskollärare i filmat material, 2016).

\section{SAMLAD ANALYS - BEGREPPSPRÖVANDE FOKUS}

Den samlade analysen utgår, som tidigare nämnts, från undervisningsinriktad och kritisk-reflektiv didaktik - en didaktik i samverkan som är under utveckling (se not 1). Analysen utmynnar i begreppen "flerstämmig undervisning" och "didaktisk (o)takt". Utifrån artikelns syfte och problem om "helhet" i undervisning kan begreppen prövas som möjliga alternativ till tidigare forskning och lärifierad didaktik där dessa begrepp inte använts.

I analysen har begreppen undervisning, omsorg och lärande både framträtt som åtskilda och som sammanflätade på olika sätt. Lärande är ett relativt högfrekvent ord medan omsorg och trygghet är lågfrekventa ord i det skriftliga materialet (se Figur 1). I läroplanen (SKOLFS 1998:16) nämns lär/a/nde också mer frekvent (cirka 50) än omsorg (cirka 10) och trygg/het (7). Vi frågar oss om det är den här relationen mellan begreppen som avses med "helhet" i styrdokumenten, det vill säga en helhet med mer lärande än omsorg och trygghet. I det filmade materialet är omsorg emellertid mer påtagligt framträdande.

Det kvantitativa inslaget i det empirinära analysledet kan tolkas stabilisera analysen och tillföra belägg för huruvida ord som omsorg, trygghet och lärande används i det skriftliga materialet, samt indikera skillnaden mellan förekomst i olika material. Att ordet lärande är mer frekvent än omsorg och trygghet i det skriftliga materialet kan relateras till begreppet lärifiering (Biesta, 2017). Vi prövar "lärifierad helhet" som uttryck för detta kvantitativa utfall.

Det högfrekventa ordet barn (se Figur 1) kan relateras till Biesta (2017) som tar avstånd från barncentrerad undervisning. Osberg och Biesta (2010) problematiserar det barncentrerade närmandet som är inriktat på att följa barn och låta dem lära sig det som de vill och är intresserade av (jfr Vallberg Roth, 2018). Barn kan beroende på uppväxtmiljö få olika erfarenheter. Och de kan svårligen visa intresse för och vilja lära sig något det inte har kännedom om. Därigenom menar Osberg och Biesta att det barncentrerade närmandet bara är ett annat sätt att vidmakthålla en existerande samhällsordning (jfr Vallberg Roth, 2018). Biesta tar också avstånd från läroplanscentrerad undervisning, $i$ termer av "learning outcome"-centrerad undervisning (Biesta, 2017; Olsen, 2018). Förskolans läroplan i Sverige (SKOLFS 1998:16), utan kunskapskrav på individnivå, är i den meningen inte learning outcome-centrerad. Under projektperioden (2016-2018) har läroplanen emellertid varit mer inriktad på lärande medan undervisning inte nämnts, vilket också kan relateras till den höga frekvensen av ordet lärande i materialet (se Figur 1). Det finns med andra ord även exempel på läroplanscentrerade spår i materialet. I artikelns 
filmade exempel är det undervisning med klassisk musik i fokus där barnen kan komma i kontakt med såväl dynamik som tempo, vilket inte är centrerat i förskolans läroplan. Exemplet kan på så sätt kopplas till något av en "världscentrerad undervisning" (Biesta, 2017; Olsen, 2018) där lärare tillför något nytt, vilket kan tolkas bidra till att öppna världen för barnen.

Sammantaget kan analysen fogas samman och prövas $i$ en kommunicerbar helhet genom begreppet "flerstämmig undervisning". I materialet framträder flerstämmiga spår av dels barncentrerad, dels läroplanscentrerad, dels världscentrerad undervisning. Didaktik har inte företrädesvis varit inriktat på omsorg och föreliggande analysexempel om undervisning $\mathrm{i}$ relation till omsorg och lärande kan utgöra ett kunskapsbidrag. Här kommer vi även att pröva begreppet"didaktisk (o)takt.

\section{Didaktisk (o)takt i helheten}

Sammantaget kan begreppen omsorg, lärande och undervisning framträda som en helhet varande i didaktisk takt eller otakt. Didaktisk takt kan uttolkas i exemplet rörande omsorgsinflätad undervisning i musik. I exemplet kan didaktisk takt hänföras till taktfull undervisning med en utmaning som är rimlig och finstämt anpassad till barnen i undervisningsgruppen (jfr Uljens, 2017). Vidare kan omsorg och tillgivenhet också vara inriktad på själva innehållet, i det här fallet musik, som förskollärare med omsorg och i samhandling med barnen kan kommunicera, undersöka och uppleva i undervisningsstund med påtaglig förundran. Det kan handla om att i finstämd, synkroniserad och balanserad taktfullhet röra sig mellan det kända, förutsägbara och det okända, oförutsägbara.

Med didaktisk otakt avses exempelvis att undervisning ibland kan framträda med spår av omsorg där förskollärare frågar sig om undervisningen blev tråkig då den för att vara trygg utgick från val av innehåll som var bekant för barnen. Sammantaget kan didaktisk otakt prövas som begrepp både i förhållande till att det å ena sidan skulle kunna bli okänsligt för barnens behov och innebära en för stor utmaning om undervisningen samtidigt och i relation till merparten av de didaktiska frågorna rörde sig bortom den trygga och välbekanta zonen. $\AA$ andra sidan kan undervisningen bli tråkig om allt är tryggt och välbekant. Didaktisk otakt kan exempelvis kopplas till undervisning som inte tycks leda till lärande eller förundran i exemplet då barnet säger: 'Jag visste redan det" (utsaga från barn i filmat material år 2016).

Vidare kan didaktisk otakt utläsas mellan den planerade, genomförda och uppföljda undervisningen. Där omsorg å ena sidan inte är påtagligt nämnd i de skriftliga dokumenten (se Figur 1), men å andra sidan är påtagligt framträdande i genomförd undervisning i de filmade samhandlingarna (jfr Löfdahl \& Folke Fichtelius, 2015; Skolinspektionen, 2018). Den så kallade helheten kan utifrån artikelns belysta exempel prövas i termer av en 
flerstämmig helhet där omsorg och lärande kan vara sammanflätade på olika sätt $\mathrm{i}$ undervisningen.

\section{Flerstämmig undervisning}

Sammantaget kan analysen i förhållande till syfte och forskningsfrågor sammanfogas och prövas $i$ en kommunicerbar helhet genom begreppet "flerstämmig undervisning". Med flerstämmig avses flera röster i många stämmor, vilket kan översättas till och inkludera olika aktörers perspektiv, skiftande vetenskapliga grunder och beprövade erfarenheter (se ovan och not 1). Exempel på olika aktörers perspektiv kan vara lärares och barns röster som uttrycks i materialet. Vetenskapliga grunder kan i artikeln röra sig mellan didaktik och musikdidaktik med referens till teorier om omsorg, lärande och undervisning. Beprövade erfarenheter kan avse utmärkande spår som framträder i materialet.

Flerstämmig undervisning kan inrymma både didaktisk takt och otakt. I sammanhanget behöver inte otakt tolkas som något ogynnsamt. Identifiering av didaktisk otakt kan exempelvis tolkas kunna driva på danandet och utprövandet av undervisning i förskola, som i följande exempel: "Är det tråkigt, för lätt, behövs det någon annan input?" (skriftlig uppföljning av undervisning i material, 2016).

Alla involverade i samverkansprojektet kan med sina mångskiftande bakgrunder och erfarenheter ses som kunskapsbärare, kunskapsbrukare och potentiella kunskapsutvecklare. Sammantaget utprövas begreppet "flerstämmig undervisning":

- för att möta unika barn och barngrupper i samhandling - vi utgår inte från "one size fits all"

- för kunskaper och värden i spontan och planerad undervisning med olika innehåll där lärande och omsorg kan vara sammanflätade på olika sätt

- $\quad$ som begrepp med potential att fläta samman olika aktörers praktiknära röster med vetenskapliga grunder och beprövade erfarenheter

- som "kompass" för att navigera, kritiskt reflektera och vidga vägar framåt (jfr Vallberg Roth, 2018)

I sammansatta och komplexa förskolepraktiker behövs vidareutvecklad kunskap för att förstå och vidga möjliggörande av sammanflätad omsorg och lärande som en helhet $i$ undervisning vilken öppnar för något nytt. Det kan i sin tur innebära att lärare mer innebördsrikt och finstämt kan möta varje barns och unika barngruppers behov av stöd och utmaningar. Begreppen flerstämmig undervisning och didaktisk (o)takt behöver vidare utprövas. 


\section{NOTER}

1 Detta treåriga samverkansprojekt bedrivs inom ramen för FoU-programmet Undervisning i förskola. Programmet genomförs i samverkan mellan tio kommuner och det fristående institutet för Innovation, Forskning och Utveckling i Skola och förskola (Ifous) och Malmö universitet (Mau, https://www.mah.se/forskning/sokpagaende-forskning/flerstammig-undervisning-och-sambedomning-i-forskola/).

Cirka 5200 har samtyckt att delta i projektet 2016-2017.

${ }^{2}$ Transkriptionsnyckeln gör inte anspråk på att transkribera alla ljud och handlingar (jfr Duranti 1997; Silverman 2011). Det rör sig snarare om partiella såväl verbala som icke-verbala handlingar, enligt följande:

"F" avser Förskollärares tal

"B" avser Barns tal och om det är flera barn involverade markeras de med en siffra som B1, B2 och så vidare.

Kursiv markering rör:

- Icke-talad kommunikation (inkluderar sång och ljudskapande)

- Blickar

- Kroppsrörelser

- Rumslig position och rörelse i rummet (barn och förskollärare)

\section{REFERENSER}

Alvesson, Mats \& Sköldberg, Kaj (2008). Tolkning och reflektion: Vetenskapsfilosofi och kvalitativ metod (2:a uppl.). Lund: Studentlitteratur.

Andersen Østergaard, Peter, Hjort, Katrin \& Skytthe Kaarsberg Schmidt, Lene (2008). Dokumentation og evaluering mellem forvaltning og padagogik. Copenhagen, Denmark: University of Copenhagen.

Areljung, Sofie (2017). Utanför experimentlådan: Kunskapsproduktion, tid och material $i$ förkolans naturvetenskapsundervisning. Umeå: Umeå universitet.

Arfwedson, Gerd (1998). Undervisningens teorier och praktiker: Didactica 6. Stockholm: HLS förlag.

Biesta, Gert (2011). God utbildning i mätningens tidevarv. Stockholm: Liber.

Biesta, Gert (2017). The Rediscovery of Teaching. New York: Routledge, Taylor \& Francis.

Björklund, Camilla \& Ahlskog-Björkman, Eva (2017). Approaches to teaching in thematic work: early childhood teachers' integration of mathematics and art. International Journal of Early Years Education 1-14. DOI: http://www-tandfonlinecom.proxy.mah.se/doi/abs/10.1080/09669760.2017.1287061

Björklund, Camilla \& Pramling Samuelsson, Ingrid (2018). Undervisning, lek, lärande och omsorg - förskolans hörnsten (s. 100-112). I Sonja Sheridan \& Pia Williams (Red.). Undervisning i förskolan: En kunskapsöversikt. Stockholm: Skolverket. 
Botö, Kerstin, Lantz-Andersson, Annika \& Wallerstedt, Cecilia (2017). ”Ja tycker om B" - Barns deltagande i läs- och skrivundervisning i förskolan. Forskning om undervisning och lärande, 2(5), 78-99.

Brante, Göran (2016). Allmän didaktik och ämnesdidaktik - en inledande diskussion kring gränser och anspråk. Nordisk Tidskrift för Allmän Didaktik, 2(1), 52-68. Elektroniskt tillgänglig, 2018-10-23:

http://noad.ub.gu.se/index.php/noad/article/view/33/18

Broström, Stig. (2012). Curriculum in preschool: Adjustment or a possible liberation? Nordic Early Childhood Education Research, 5(11), 1-14. DOI: https://doi.org/10.7577/nbf.419

Comenius, Johan A. (1632/1989). Modersskolan eller om barns omvairdnad och fostran under de sex första levnadsåren (översättning och inledning av Tomas Kroksmark). Göteborg: Göteborgs universitet.

Dahlberg, Gunilla \& Elfström, Ingela (2014). Pedagogisk dokumentation i tillblivelse. Pedagogisk forskning i Sverige, 19(4-5), 268-296.

Dalgren, Sara (2017). Att göra pedagogisk praktik tillsammans: Socialt samspel i förskolans vardag. Linköping: Linköpings universitet.

Davies, Karen (1996). Omsorg om barn - önskningar och realiteter: En sociologisk studie av daghem. Stockholm: Carlsson.

Doverborg, Elisabeth, Pramling, Niklas \& Pramling Samuelsson, Ingrid (2013). Att undervisa barn i förskolan. Stockholm: Liber.

Duranti, Alessandro (1997). Transcription: From writing to digitized images. I: Alessandro Duranti, Linguistic Anthropology (s. 122-161). New York: Cambridge University Press.

Dysthe, Olga. (1993). Writing and Talking to Learn: A theory-based, interpretive study in three classrooms in the USA and Norway. Norway, Tromsö: University of Tromsö.

Eidevald, Christian, Engdahl, Ingrid, Frankenberg, Sofia, Lenz Taguchi, Hillevi \& Palmer, Anna (2018). Omsorgsfull och lekfull utbildning och undervisning i förskolan. I S. Sheridan \& P. Williams (Red.). Undervisning i förskolan: En kunskapsöversikt (s. 81-91). Stockholm: Skolverket.

Gustavsson, Laila \& Thulin, Susanne (2017)._Lärares uppfattningar av undervisning och naturvetenskap som innehåll i förskolans verksamhet. Nordic Studies in Science Education, NorDiNa, 13(1), 81-96. DOI: http://dx.doi.org/10.5617/nordina.2549

Halldén, Gunilla (2001). Omsorgsbegreppet i förskolan. Olika infallsvinklar på ett begrepp och dess relation till en verksamhet. Inledning. I: Omsorgsbegreppet i förskolan. Rapport frän Nätverket för barnomsorgsforskning i Göteborg 20-21 november 2000.

Halldén, Gunilla (2007). Den moderna barndomen. Stockholm: Carlssons Bokförlag. 
Halldén, Gunilla (2009). Daghem eller förskola - om beteckningars innebörder. I Judith Lind, Cecilia Lindgren, Mats Sjöberg \& Karin Zetterqvist Nelson (Red.). Historien, barnen och barndomarna: vad är problemet?: en vänbok till Bengt Sandin (s. 125143). Linköping: Linköpings universitet.

Hammarström-Lewenhagen, Birgitta (2013). Den unika möjigheten - en studie av den svenska förskolemodellen 1968-1998. Stockholm: Stockholms universitet.

Hammer, Anne S.E. (2012). Undervisning i Barnehagen? I Elin Erikssen Ödegaard (Red.). Barnehagen som danningsarena (s. 223-244). Oslo Fagbokforlaget.

Harju-Luukkainen, Heidi \& Kultti, Anne (Red.) (2017). Undervisning $i$ flerspråkig förskola. Malmö: Gleerups.

Hedefalk, Maria (2014). Förskola för hällbar utveckling: Förutsättningar för barns utveckling av handlingskompetens för hallbar utveckling. Uppsala: Uppsala universitet.

Holmberg, Ylva \& Vallberg Roth, Ann-Christine (2018). Flerstämmig musikundervisning i förskola. Barn, 36(3-4), 79-94. DOI: https://doi.org/10.5324/barn.v36i3-4.2898

Holmqvist Olander, Mona (Red.) (2013). Learning study i förskolan. Lund: Studentlitteratur.

Ingerman, Åke \& Wickman, Per-Olof (2015). Towards a teachers' professional discipline. I Pamela Burnard, Britt-Marie Apelgren, \& Nese Cabaroglu (Red.). Transformative teacher research: In theory and practice for the C21st (s. 167-179). Rotterdam: Sense Publishing.

Illeris, Knud (2015). Lärande. (2:a uppl.) Lund: Studentlitteratur.

Jonsson, Agneta, Williams, Pia \& Pramling Samuelsson, Ingrid (2017). Undervisningsbegreppet och dess innebörder uttryckta av förskolans lärare. Forskning om undervisning och lärare, 5(1), 90-109. Elektroniskt tillgänglig, 2018-10-23: http://www.forskul.se/tidskrift/nummer18/undervisningsbegreppet och dess i nneborder uttryckta av forskolans larare

Josefson, Mie (2018). Det ansvarsfulla mötet: En närhetsetisk analys av omsorgens innebörder i förskolan. Stockholm: Stockholms universitet.

Klafki, Wolfgang. (1997). Kritisk-konstruktiv didaktik. I Michael Uljens (Red.). Didaktik (s. 215-228). Lund: Studentlitteratur.

Lenz-Taguchi, Hillevi (2010/2012). Pedagogisk dokumentation som aktiv agent: Introduktion till intra-aktiv pedagogik. Malmö: Gleerup.

Lenz Taguchi, Hillevi \& Palmer, Anna (2017). Dokumentation för lärande. SEMLA: Socioemotionellt och materiellt lärande i förskolan. I Anne-Li Lindgren, Niklas Pramling \& Roger Säljö (Red.). Förskolan och barns utveckling: Grundbok för förskollärare (s. 245-259). Malmö: Gleerup. 
Ljung-Djärf, Agneta, Magnusson, A. \& Peterson, S. (2014). From doing to learning: Changed focus during a pre-school learning study project on organic decomposition. International Journal of Science Education, 36(4), 659-676. DOI: http://dx.doi.org/10.1007/s13158-012-0067-9

Lindgren, Anne-Li (2016). Etik, integritet och dokumentation i förskolan. Malmö: Gleerups.

Löfdahl, Annika \& Folke-Fichtelius, Maria (2015). Förskolans nya kostym: Omsorg i termer av lärande och kunskap. KAPET, 10(1), 1-14. Elektroniskt tillgänglig, 201810-23: http://www.diva-portal.org/smash/get/diva2:767364/FULLTEXT01.pdf

Marton, Ference. (2015). Necessary Conditions of Learning. London: Routledge.

Mascolo, Michael F. \& Fischer, Kurt (2015). Dynamic Development of Thinking, Feeling and Acting. I Richard M. Lerner, Thomas Leventahl \& Marc H. Bornstein (Red.). Handbook of Child Psychology and Developmental Science, Theory and Method (kapitel 4). Hoboken, NJ: Wiley.

Melker, Kristina, Mellgren, Elisabeth \& Pramling Samuelsson, Ingrid. (2018). Undervisning i förskolan - en fråga om att stötta och att skapa gemensamt fokus. Forskning om undervisning \& lärande, 6, 64-86.

Nielsen, Frede V. (2006). Almen musikdidaktik (3:e uppl.). Køpenhavn: Akademisk forlag.

Noddings, Nel (1984). Caring: A Feminine Approach to Ethics and Moral Education. Berkeley: University of California Press.

Noddings, Nel (2012). The language of care ethics. Knowledge quest, 40(5), 52-56.

OECD (2017). Starting Strong 2017: Key OECD Indicators on Early Childhood Education and Care. Paris: OECD. Elektroniskt tillgänglig, 2017-06-21: http://www.keepeek.com/Digital-Asset-Management/oecd/education/startingstrong-2017 9789264276116-en\#page71

Olsen, John Villy (2018). En tredje vej: Verden i centrum. Folkeskolen 11. Elektroniskt tillgänglig 2018-06-12: https://www.folkeskolen.dk/636818/en-tredje-vej-verdeni-centrum

Osberg, Deborah. \& Biesta, Gert (2010). The end/s of education: Complexity and the conundrum of the inclusive educational curriculum. International Journal of Inclusive Education, 14(6), 593-607. DOI: https://doi.org/10.1080/13603110802530684

Palmer, Anna (2010). Att bli matematisk: Matematisk subjektivitet och genus $i$ lärarutbildningen för de yngre åldrarna. (Doktorsavhandling). Stockholm: Stockholms universitet.

Palmer, Anna (2011). Hur blir man matematisk: Att skapa nya relationer till Matematik och genus $i$ arbetet med yngre barn. Stockholm: Liber. 
Palmer, Anna, Unga, J. \& Hultman, K. (Red.) (2017). Svindlande matematik: Estetik, lek och utforskande i förskolan. Malmö: Gleerup.

Peirce, Charles. S. (1903/1990). Pragmatism och kosmologi: V alda uppsatser i översättning av Richard Matz och med inledning av Margareta Bertilsson och Peder Voetmann Christiansen. Göteborg, Sweden: Daidalos.

Persson, Sven (2015). Delstudie 4: Pedagogiska relationer i förskolan. . I Ingegerd Tallberg Broman (Red.). Förskola: Tidig intervention - SKOLFORSK (s. 117-135). Stockholm: Vetenskapsrådet.

Proposition 2009/10:165, Den nya skollagen - för kunskap, valfribet och trygghet. Stockholm: Utbildningsdepartementet.

Rapley, Tim. (2011). Some pragmatics of qualitative data analysis. I David Silverman (Red.). Qualitative research: Issues of theory, method and practice (s. 273-290). Los Angeles, CA: Sage.

RFR, Rapporter Från Riksdagen (2012/2013). Hur kan ny kunskap komma till bättre användning $i$ skolan: Del $\quad$. Elektroniskt tillgänglig, 2014-04-08: http://www.riksdagen.se/sv/Dokument-Lagar/Utredningar/Rapporter-franriksdagen/Hur-kan-ny-kunskap-komma-till- H00WRFR10/

Rosenqvist, Mia M. (2000). Undervisning i förskolan? En studie av förskollärarstuderandes föreställningar. Stockholm: HLS Förlag.

Sæbbe, Per-Einar \& Pramling Samuelsson, Ingrid (2017). Hvordan underviser barnehagelærere? Eller gjør de ikke det i barnehagen?.Journal of Nordic Early Childhood Educatio Research,14(7), 1-15. DOI: 10.7577/nbf.1731

SFS 2010: 800. Skollagen.

Sheridan, Sonja \& Williams, Pia (Red.) (2018). Undervisning i förskolan: En kunskapsöversikt. Stockholm: Skolverket.

Silverman, David (Red.) (2011). Qualitative Research: Issues of Theory, Method and Practice (3:e uppl.). Los Angeles: Sage.

SKOLFS 1998:16. Läroplan för förskolan Lpfö 98: Reviderad 2016. Stockholm: Utbildningsdepartementet.

SKOLFS 2018:50. Läroplan för förskolan Lpfö 18. Stockholm: Utbildningsdepartementet.

Skolinspektionen (2016). Förskolans kvalitet och måluppfyllelse 2015-2017: Delrapport 1. Elektroniskt tillgänglig 2018-07-10: https://www.skolinspektionen.se/globalassets/publikationssok/regeringsrapport er/redovisningar-regeringsuppdrag/2016/forskolerapport1.pdf

Skolinspektionen (2018). Slutrapport: Förskolans kvalitet och måluppfyllelse - ett treärigt regeringsuppdrag att granska förskolan. Stockholm: Skolinspektionen. 
Skolverket (2012). Uppföljning, utvärdering och utveckling - pedagogisk dokumentation. Stockholm: Fritzes.

Skolverket (2018). Redovisning av uppdrag om översyn av läroplan för förskola. Dnr: 2017:783. Stockholm: Skolverket.

Sylva, Kathy, Melhuish, Edward, Sammons, Pam, Siraj-Blatchford, Iram \& Taggart, Brenda (2010). Early childhood matters: Evidence from the effective pre-school and primary education project. Abingdon, Oxon, England: Routledge.

Tallberg Broman, Ingegerd (Red.) (2015). Förskola: Tidig intervention - SKOLFORSK. Stockholm: Vetenskapsrådet.

Tavory, I. \& Timmermans, S. (2014). Abductive Analysis: Theorizing Qualitative Research. Chicago: University of Chicago Press.

Thelin, Katina (2013). Mellan varumärke och gemensamt raster: Skilda sätt att se verksambetsidéer för pedagogisk verksambet. Karlstad: Karlstads universitet.

Uljens, Michael (Red.) (1997). Didaktik - teori, reflektion och praktik. Lund: Studentlitteratur.

Uljens, Michael (2017). Att teoretisera pedagogikens relationer. I Herner Sæverot \& Tobias Werler (Red.). Pedagogikkens språk (s. 62-87). Oslo: Gyldendal.

Uljens, Michael \& Ylimaki, Rose (2017). Bridging Educational Leadership, Curriculum Theory and Didaktike - Non-affirmative Theory of Education. Dordrecht: Springer.

Vallberg Roth, Ann-Christine (2017). Del IV: Att undervisa, dokumentera och sambedöma - stöd för kritisk reflektion. I L. Rubinstein Reich, I. Tallberg Broman \& A.-C. Vallberg Roth, Professionell yrkesutöuning i förskola - kontinuitet och förändring (s. 146-256). Lund: Studentlitteratur.

Vallberg Roth, Ann-Christine (2018). What may characterise teaching in preschool? The written descriptions of Swedish preschool teachers and managers in 2016. Scandinavian Journal of Educational Research. https://doi.org/10.1080/00313831.2018.1479301

Vallberg Roth, Ann-Christine \& Tallberg Broman, Ingegerd (2018). Undervisning i förskola - med koppling till ett samverkansprojekt. I Sonja Sheridan och Pia Williams (Red.). Undervisning i förskolan: En kunskapsöversikt (s. 62-80). Stockholm: Skolverket.

Vetenskapsrådet (2017). God forskningssed. Stockholm: Vetenskapsrådet.

Williams, Pia, Sheridan, Sonja \& Pramling Samuelsson, Ingrid (2001). Samlärande - en forskningsöversikt. Stockholm: Liber. 